\title{
Neonatal Hearing Loss
}

National Cancer Institute

\section{Source}

National Cancer Institute. Neonatal Hearing Loss. NCI Thesaurus. Code C50668.

Partial or complete loss of the ability to detect or understand sounds present in an infant within its first month after birth. 